\title{
Poczucie funkcjonalności rodzinnej w percepcji studentów pogranicza północno-wschodniej Polski $^{1}$
}

Streszczenie: Rodzina jest środowiskiem, które w największym stopniu pozostawia swój ślad i piętno w strukturze tożsamości człowieka. Wynika to zarówno z szerokiego w swoich ramach, jak i permanentnego charakteru oddziaływań. Każda rodzina wytwarza i reguluje swoistą rodzinną tożsamość. W tekście przedstawione zostały wyniki badań prowadzonych w grupie młodzieży akademickiej dotyczących poziomu poczucia satysfakcji z funkcjonowania ich rodziny pochodzenia oraz próba uchwycenia czynników je warunkujących. Analizy prezentowanych modeli ukazują obraz młodzieży akademickiej, która w swoich orientacjach życiowych bardzo ceni rodzinę, jako podstawowy punkt odniesienia w konstrukcie ich własnej tożsamości. Widoczne jest duże zorientowanie na wspólnotowy charakter jej funkcjonowania, jakość relacji poszczególnych członków systemu oraz możliwość własnego partycypowania w zasadach i regułach wypracowywanych w rodzinie. Kształtująca się w nich tożsamość rodzinna jest pewnego rodzaju negocjowanym tworem uznanych przez nich tradycji rodzinnych, z jednoczesnymi zarysowanymi tendencjami dekonstrukcji dotychczasowych modelowych sposobów ujmowania struktury rodzinnej, na rzecz poszukiwania innego spojrzenia, które jest rodzajem adaptacji systemu do dynamicznie zmieniających się warunków społeczno-kulturowych.

Słowa kluczowe: system rodzinny, tożsamość rodzinna, identyfikacja, młodzież, poczucie funkcjonalności rodzinnej, pedagogika międzykulturowa

\section{Wprowadzenie}

Ze względu na szerokie spektrum, jak i permanentny charakter oddziaływań to rodzina jest środowiskiem, które w największym stopniu pozostawia

1 Artykuł ukazuje fragment badań, które w całości zostały zaprezentowane w książce: Bajkowski T. 2018. U źródet tożsamości rodzinnej. System rodzinny w percepcji młodzieży akademickiej. Warszawa: Wydawnictwo Naukowe Scholar. 
swój ślad i piętno w strukturze tożsamości człowieka. Stopień wpływu tych oddziaływań jest uwarunkowany charakterystyką rozwojową cyklu życia rodziny, jakością relacji zachodzących w jej obrębie oraz specyfiką przepływu transmisji międzygeneracyjnej w tej określonej przestrzeni interakcji. Każda rodzina wytwarza i reguluje swoistą rodzinną tożsamość, której poczucie polega na „(...) przeżywaniu siebie jako bycie kimś, kto niezależnie od zmieniających się okoliczności, zmiany stanu fizycznego, zmiany relacji pozostaje wciąż sobą" (Barbaro, 1999, s. 46). Zakładam, że każdy element systemu rodzinnego może pomagać innym elementom czerpać z wzajemnych zasobów oraz z dynamiki relacji zachodzącej w jego przestrzeni. Dla uzyskania optymalizacji procesu budowania własnej tożsamości przez człowieka ważne wydaje się osiągnięcie przez niego poczucia rodzinnej koherencji (Antonovsky, 1995, s. 34). Można ją traktować jako psychospołeczny kapitał jednost$\mathrm{ki}$, pewnego rodzaju wzorzec postrzegania rodziny w aspekcie poznawczym, emocjonalnym oraz instrumentalnym (Werner, 2013, ss. 73-83). Pomaga to w odpowiedzi na ważne pytania egzystencjalne dotyczące: miejsca jednostki w rodzinie, specyfiki podziału ról w rodzinie, stanów emocjonalnych dominujących wśród jej członków, zdolności, które przejawia rodzina w konfrontacji z zadaniami rozwojowymi i kryzysami natury wewnętrznej i zewnętrznej.

W warstwie teoretycznej główną teorią, która posłużyła do zoperacjonalizowania kategorii poznawczych, był Systemowy Model Rozumienia Rodziny. To określone podejście do systemu rodzinnego, za punkt wyjścia przyjmuje analizę: jej historii, procesu rozwoju, aktualnej struktury i wzorów relacji oraz jej miejsca w hierarchii innych systemów (Józefik, 2003, s. 22). Aby opisywać rodzinę jako system, należy uwzględniać trzy poziomy analiz: biologiczny, indywidualny i społeczny. Jej funkcjonalność natomiast ocenia się poprzez to, jak członkowie rodziny radzą sobie ze zmianami wynikającymi z cyklu życia rodziny, naturalnymi procesami rozwojowymi oraz nieprzewidywanymi wydarzeniami losowymi. W obszarze nauk humanistycznych i społecznych najbardziej widoczną próbę asymilacji teorii systemowej można dostrzec w psychologii i psychoterapii. Systemem nazywamy tu zbiór elementów powiązanych ze sobą interakcjami i zależnościami, stanowiącymi przez to jedną całość, zdolną do funkcjonowania w myśl określonych reguł (Barbaro, 1999). W myśl doktryny teorii systemowej rzeczywistość składa się z systemów i subsystemów, które pozostają z sobą w stałej interakcji. Podejście systemowe na gruncie problematyki rodzinnej zostało rozwinięte przez Salvadora Minuchina (Minuchin, 1974; Grzesiuk, 1987, ss. 33-48), twórcę 
Strukturalnej Teorii Rodzin, oraz Murraya Bowena (Bowen, 1978), autora Teorii Systemów Rodzinnych. Obie teorie odwołują się do powtarzających się wzorów wzajemnych odniesień członków rodziny wobec siebie regulujących zachowanie i podtrzymujących system. Wzajemne oddziaływanie członków rodziny oraz ich sposoby komunikacji Bowen nazywa wzorami relacyjnymi (wynikające z poziomu dyferencjacji „Ja”), a Minuchin strukturą rodziny (podsystemy oraz granice między nimi) (Kaleta, 2011, ss. 141-158). System posiada określony zespół norm, zasad, środków podtrzymujących jego spójność oraz sposobów zaspokajania potrzeb członków swojej rodziny.

Oprócz wcześniej wspomnianych teorii filozofię systemowego podejścia do rodziny reprezentują: Model Funkcjonowania Rodziny McMastera (Miller, Ryan, Keitner, Bishop iEpstein, 2000, ss. 168-189), Bioekologiczna Teoria Systemów Bronfenbrennera (Bronfenbrenner, 2005), Model Procesu Funkcjonowania Rodziny (Skinner, Steinhauer i Sitarenios, 2000, ss. 190-210) czy Model Systemowy Beaversa Funkcjonowania Rodziny (Beavers i Hampson, 2000, ss. 128-143). Jednym z wariantów teorii rodziny jako systemu społecznego jest również Model Kołowy Systemów Matżeńskich i Rodzinnych Olsona (Circumplex Model) (Olson, Sprenkle i Russell, 1979, ss. 3-28; Olson, 2011, ss. 64-80). Model, opracowany przez zespół pod kierunkiem Davida H. Olsona, bazuje na trzech głównych wymiarach funkcjonowania rodziny: spójności, elastyczności (adaptacyjności) i procesach komunikacyjnych. Spójność relacji odnosi się do więzi emocjonalnej istniejącej między wszystkimi członkami rodziny. Elastyczność relacji określa jakość przywództwa w rodzinie oraz sposoby jego przejawiania się. Ten wymiar funkcjonowania diagnozuje sposób organizacji rodziny, podział ról rodzinnych, reguły rodzinne oraz dominujące sposoby negocjacji. Wymiar komunikacyjny (facylitujący) pomaga rodzinie $\mathrm{w}$ dokonywaniu zmian $\mathrm{w}$ poziomie spójności i elastyczności relacji rodzinnych. W myśl tej koncepcji nasilenie spójności i elastyczności relacji rodzinnych może przyjmować dwa zasadnicze poziomy: zrównoważony lub niezrównoważony. Niezrównoważenie w zakresie spójności dotyczy jej dużego nasilenia (w postaci splątanej relacji) lub bardzo niskiego nasilenia (w postaci niezaangażowania i powstającej w wyniku tego relacji bez więzi). Niezrównoważenie elastyczności natomiast może przyjmować postać dużego nasilenia (chaos relacji rodzinnych) lub skrajnie niskiego nasilenia (sztywność relacji rodzinnych). Zdaniem twórców tego modelu istnieje duży związek pomiędzy zrównoważonym poziomem spójności i elastyczności a zdrowym funkcjonowaniem systemu rodzinnego oraz niezrównoważonym poziomem spójności i elastyczności a problemami w jego funkcjonowaniu. 
Praktyczną egzemplifikacją tego ostatniego podejścia jest narzędzie diagnostyczne (Profil Rodziny), którego adaptacji na warunki polskie dokonał m.in. Zbigniew Gaś (Gaś, 1994, ss. 66-91; Gaś, 2004). Analiza funkcjonowania systemu rodzinnego przez poszczególnych jej członków pozwala oszacować poziom spójności i adaptacyjności rodziny, poznać jakość procesów komunikacyjnych oraz nasilenie czynników dezorganizacji życia rodzinnego. Efektem analiz jest określenie indywidualnego poczucia poziomu funkcjonalności systemu rodzinnego w percepcji poszczególnych jej członków. To narzędzie badawcze zostało wykorzystane również w toku analizy systemu rodzinnego młodzieży akademickiej, której fragmenty wyników zostaną zaprezentowane w tym artykule.

\section{Koncepcja badań własnych}

Analizując system rodzinny rozumiany jako zbiór elementów powiązanych ze sobą interakcjami i zależnościami, stanowiącymi przez to jedną całość, zdolną do funkcjonowania w myśl określonych reguł (Barbaro, 1999), założyłem, że należy zbadać zarówno jego strukturę, jak i istotę funkcjonowania. Podjęte przeze mnie badania miały na celu ukazać pewne uwspólnione, ale także specyficzne i unikatowe cechy systemu rodziny pochodzenia badanej młodzieży akademickiej.

Wybór określonej grupy badanej, którą stanowiła młodzież akademicka, wynikała z wyjątkowości tego etapu życia młodego człowieka, który jest niejako zawieszony pomiędzy rodziną pochodzenia, a tworzeniem wizji już własnego systemu rodzinnego. W tym przypadku tożsamość rodzinna ma konstrukcję trajektoryjną, stanowiącą pewien pomost na osi czasu. Dotyczy bowiem zarówno przeszłości, obecnej percepcji systemu, jak i perspektywy przyszłości, antycypowania nadchodzących konstruktów rodzinnych. Młodzież, poprzez swój kontestacyjny charakter przeżywania dylematów tożsamościowych, ma możliwość przedefiniowania istoty idei funkcjonowania rodziny, twórczego przekształcenia sposobu formowania się jej struktury oraz wewnętrznej renegocjacji tworzących ją zasad i celów.

Celem całości badań (których tylko fragment prezentuję w artykule) była próba zdiagnozowania systemów rodzinnych młodzieży akademickiej, poznania jej struktury, specyfiki zachodzących tam interakcji, źródeł kształtujących postawy życiowe badanych osób, wzorców osobowych i społecznych ważnych dla badanych studentów, profili rodzinnych oraz identyfikacji głównych uwarunkowań obserwowanych obrazów rodzin pochodzenia (Bajkow- 
ski, 2018). Analiza wyników badań miała posłużyć skonstruowaniu wniosków dla praktyki, natury diagnostycznej i metodycznej, które mogłyby być przydatne w tworzeniu konkretnych procedur identyfikujących specyfikę systemu rodzinnego oraz ułatwić planowanie i kontrolę procesów edukacyjnych, profilaktycznych i interwencyjnych.

W badaniach wzięło udział 670 osób. Po zweryfikowaniu kompletności wypełnionego kwestionariusza ankiety w kluczowych kategoriach badawczych i odrzuceniu tych z istotnymi brakami danych do ostatecznej analizy zostały zakwalifikowane 633 kwestionariusze badanej młodzieży akademickiej. W celu zachowania reprezentatywności grupy młodzieży akademickiej badania były prowadzone na różnych typach największych uczelni wyższych regionu północno-wschodniej Polski (Uniwersytecie w Białymstoku, Politechnice Białostockiej oraz Uniwersytecie Medycznym w Białymstoku) i różnych specjalnościach (bardziej sfeminizowanych, bardziej zmaskulinizowanych i takich o równej proporcji płci), tak by zachować pewną proporcjonalność grupy badanych kobiet i mężczyzn.

\section{Profile rodzin pochodzenia badanej młodzieży}

U podstaw budowania koncepcji badawczej stało założenie, że obraz systemu rodziny pochodzenia młodzieży akademickiej daje podstawy do wyłonienia czynników chroniących oraz destabilizujących ten system. Poczucie rodzinnej koherencji (zrozumiałości, zaradności i sensowności) (Antonovsky, 1995, s. 34) w powiązaniu z prężnością rodzinną (Walsh, 2012, ss. 399-427) daje możliwość przeciwstawiania się sytuacjom stresowym w różnych przestrzeniach funkcjonowania człowieka, stymulują, przy tym układ adaptacyjny pomocny w pozytywnym przejściu sytuacji kryzysowych. Świadczy to o niebywałej sile systemu rodzinnego, dużo większej niż prosty zbiór zasobów stanowiących go jednostek.

W toku badań został wykorzystany kwestionariusz Profil Rodziny, w wersji opracowanej przez Zbigniewa B. Gasia (Gaś, 2004; Gaś, 1994, ss. 66-91). Inwentarz Profil Rodziny przeznaczony jest do diagnozy funkcjonowania systemu rodzinnego i składa się z 86 stwierdzeń, które tworzą sześć skal. Trzy $\mathrm{z}$ nich dotyczą pozytywnych wymiarów funkcjonowania systemu rodzinnego (spójność rodziny (SR), adaptacyjność rodziny (A) oraz wzajemne zrozumienie (WZ)), natomiast trzy kolejne dotyczą trudności, jakie może przeżywać rodzina (role rodzinne (RR), trudności rozwojowe (TR) oraz dezintegracja rodzinna (DR)). Suma punktów uzyskanych w poszczególnych skalach uka- 
zuje poziom natężenia określonego wymiaru funkcjonowania systemu rodzinnego osoby badanej.

Kompilacja wyników uzyskiwanych w poszczególnych skalach stanowi podstawę do obliczania wskaźnika Poczucia funkcjonalności (PF). Oblicza się go na wartościach surowych na podstawie wzoru: $\mathrm{PF}=(\mathrm{SR}+\mathrm{A}+\mathrm{WZ})$ $(\mathrm{RR}+\mathrm{TR}+\mathrm{DR})$.

Badanie inwentarzem Profil rodziny pozwala na oszacowanie poziomu jej spójności i adaptacyjności, określenie jakości zachodzących tam procesów komunikacyjnych oraz wykazanie nasilenia czynników dezorganizujących życie rodzinne, a w konsekwencji określenie indywidualnego poczucia poziomu jej funkcjonalności.

W celu sprawdzenia rzetelności i adekwatności wybranego narzędzia dokonano interkorelacji poszczególnych skal na podstawie uzyskanych wyników badanej grupy. Miało to na celu zbadanie uwarunkowań poczucia funkcjonalności rodzinnej oraz wzajemnej zależności pozytywnych i negatywnych skal profilu rodzinnego badanej młodzieży akademickiej.

Tabela 1. Interkorelacje skal Profilu Rodziny w grupie badanych studentów

\begin{tabular}{|c|c|c|c|c|c|c|c|c|c|}
\hline & SR & A & WZ & RR & TR & DR & PF \\
\hline \multirow{14}{*}{$\begin{array}{l}\text { rho } \\
\text { Spearmana }\end{array}$} & \multirow{2}{*}{ Spójność rodziny } & Współczynnik korelacji & & ,733*" &, $486^{\circ 3}$ &,$- 187^{\prime *+}$ &,$- 406^{20}$ &,$- 583^{* \prime}$ & ,752" \\
\hline & & Istotność dwustronna) & & 000 & 000 & ,000 & ,000 & , 000 & 000 \\
\hline & \multirow{2}{*}{$\begin{array}{l}\text { Adaptacyjność } \\
\text { rodziny }\end{array}$} & Współczynnik korelacji & ,733* & & $669^{* *}$ &,$- 307^{*+*}$ &,$- 458^{* 2}$ &,$- 719^{s}$ &, $852^{* 2}$ \\
\hline & & Istotność dwustronna) &, 000 & &, 000 &, 000 &, 000 &, 000 & ,000 \\
\hline & \multirow{2}{*}{$\begin{array}{l}\text { Wzajemne } \\
\text { zrozumienie }\end{array}$} & Współczynnik korelacji & $486^{* *}$ & ,669" & &,$- 239^{\prime \prime \prime}$ &,$- 375^{30}$ &,$- 620^{\prime \prime}$ & ,698* \\
\hline & & Istotność (dwustronna) &, 000 &, 000 & & ,000 &, 000 &, 000 & ,000 \\
\hline & \multirow{2}{*}{ Role rodzinne } & Współczynnik korelacji &,$- 187^{* *}$ &,$- 307^{\prime \prime}$ &,$- 239^{* * 4}$ & &, 073 & ,394: &,$- 558^{4}$ \\
\hline & & Istotność (dwustronna) &, 000 & ,000 & ,000 & & 065 & 000 & 000 \\
\hline & \multirow{2}{*}{$\begin{array}{l}\text { Trudności } \\
\text { rozwojowe }\end{array}$} & Współczynnik korelacji &,$- 406^{* \prime \prime}$ &,$- 458^{3}$ &,$- 375^{*}$ & 073 & &, $319^{* *}$ &,- 572 \\
\hline & & Istotność (dwustronna) & ,000 & 000 & ,000 & 065 & & 000 & 000 \\
\hline & \multirow{2}{*}{$\begin{array}{l}\text { Dezintegracja } \\
\text { rodzinna }\end{array}$} & Współczynnik korelacji &,$- 583^{* *}$ &,$- 719^{\prime \prime}$ &,$- 620^{m+\infty}$ & $394^{* 0}$ & $319^{* *}$ & &,$- 847^{\prime \prime}$ \\
\hline & & Istotność (dwustronna) &, 000 &, 000 &, 000 & 000 &, 000 & &, 000 \\
\hline & \multirow{2}{*}{$\begin{array}{l}\text { Poczucie } \\
\text { funkcjonalności }\end{array}$} & Współczynnik korelacji &, $752^{* *}$ & 852 & ,698 &,$- 558^{* *+}$ &,$- 572^{* 3}$ &,$- 847^{\prime \prime}$ & \\
\hline & & Istotność (dwustronna) & 000 & 000 & 000 & 000 & 000 & ,000 & \\
\hline
\end{tabular}

Badania w grupie młodzieży akademickiej wykazały szereg związków pomiędzy poszczególnymi skalami Profilu Rodziny. Zaobserwowano pozytywny związek pomiędzy poczuciem funkcjonalności rodziny (PF) a wysokim poziomem spójności (skala SR), adaptacyjności (Skala A) oraz wzajemnego zrozumienia (skala WZ) w rodzinie pochodzenia badanych osób. Z drugiej 
strony wysoki współczynnik poczucia funkcjonalności był związany z niskimi wartościami w zakresie występowania patologicznych ról rodzinnych (skala RR), występujących trudności rozwojowych (skala TR) oraz poziomu dezintegracji rodzinnej (skala DR). Generalnie można było zaobserwować wzajemne zależności w zakresie trzech pozytywnych wymiarów funkcjonowania rodzinnego (skale: $\mathrm{S}, \mathrm{A}, \mathrm{WZ}$ ) oraz trzech negatywnych wymiarów funkcjonowania (skale: RR, TR, DR). Świadczy to rzetelności wykorzystywanego narzędzia oraz adekwatności zawartym w nich skal.

\section{Model predyktorów poczucia funkcjonalności rodzinnej}

Główny wynik badania w postaci poczucia funkcjonalności, który scala wszystkie skale profilu rodzinnego, został poddany analizie za pomocą modelu regresji. Miało to na celu poszukiwanie predyktorów, które wprost proporcjonalnie lub odwrotnie proporcjonalnie warunkują jego wysoki wskaźnik. Prezentowana w artykule analiza została wykonana przy pomocy regresji hierarchicznej, w celu wyodrębnienia grup wzajemnie powiązanych czynników, które uwzględnione łącznie tworzą model wyjaśniający zmienność wytypowanych, głównych elementów obrazu systemu rodziny pochodzenia badanych osób. Założeniem konstrukcji modelu regresji była próba interkorelacji obrazu systemu rodziny pochodzenia osób badanych w celu wykazania głównych predyktorów poczucia funkcjonalności rodzinnej badanych studentów. Interesujące wydaje się uchwycenie tego, jakie elementy charakterystyki rodzinnej składają się na globalne poczucie jej funkcjonalności. Ukazało to całą sieć uwarunkowań obrazu systemu rodzinnego studentów, złożonych z komponentów tożsamości indywidualnej i familijnej.

W myśl podejścia systemowego rozwój jednostki jest w dużej mierze rezultatem interakcji pomiędzy różnymi wymiarami życia rodzinnego (Rostowski, 2006, ss. 127-143). Poczucie funkcjonalności rodzinnej stanowił w przedstawianych badaniach kluczowy parametr obrazu rodziny pochodzenia badanych studentów. Ukazuje on bowiem zarówno poziom spójności i adaptacyjności rodzinnej, jakość zachodzących tam procesów komunikacyjnych, jak i nasilenie czynników dezorganizujących życie rodzinne. Funkcjonalna rodzina charakteryzuje się pozytywnymi więziami emocjonalnymi pomiędzy jej członkami, umiejętnością przystosowywania się do zmieniających się warunków życia rodzinnego, sprawnym przebiegiem procesów komunikacyjnych, przy jednoczesnym małym nasileniu trudności rozwojowych i dezintegracji rodzinnej (Paufal-Struzik i Szewczyk, 2016, ss. 69-85). Założeniem badań była próba 
uchwycenia indywidualnego doświadczania poczucia funkcjonalności rodzinnej, której obraz zmienia się w różnych okresach życia (Przetacznik-Gierowska, 2002, s. 140). Badani studenci z racji osiągania względnej samodzielności, będąc zarówno obserwatorami, jak i uczestnikami życia rodzinnego, prezentują pewien poziom dystansu, który potencjalnie zwiększa obiektywizm deklaracji. Przy podstawianiu do modelu pakietów ewentualnych predyktorów w sposób celowy zrezygnowano zarówno z cech społeczno-demograficznych osób badanych, jak i wyników osiąganych w poszczególnych skalach Profilu Rodziny. Osiągane przez respondentów poziomy poszczególnych skal budowały ogólny poziom poczucia funkcjonalności rodziny, więc w sposób oczywisty są silnie z nim skorelowane, a ich interkorelacja została przedstawiona w tabeli 1. Wyniki eksploracji modelu poczucia funkcjonalności rodzinnej grupy badanej zostały zaprezentowane $\mathrm{w}$ dwóch tabelach: 2 (prezentującej podsumowanie modelu) oraz 3 (prezentującej zmienne modelu).

Tabela 2. Regresja hierarchiczna dla zmiennej „Poczucie funkcjonalności rodzinnej” w grupie badanych studentów. Podsumowanie modelu

\begin{tabular}{|c|c|c|c|c|}
\hline \multicolumn{4}{|c|}{ Model - Podsumowanie } \\
\hline Model & $\mathrm{R}$ & R-kwadrat & Skorygowane R-kwadrat & Błąd standardowy oszacowania \\
\hline &, $638^{\mathrm{g}}$ &, 407 &, 390 & 1,320568004387876 \\
\hline
\end{tabular}

Tabela 3. Regresja hierarchiczna dla zmiennej „Poczucie funkcjonalności rodzinnej” w grupie badanych studentów. Zmienne w modelu

\begin{tabular}{|l|c|c|c|c|c|}
\hline \multirow{2}{*}{ Predyktory } & \multicolumn{2}{|c|}{$\begin{array}{c}\text { Współczynniki } \\
\text { biestandaryzowane }\end{array}$} & $\begin{array}{c}\text { Współczynniki } \\
\text { standaryzowane }\end{array}$ & \multirow{2}{*}{$\mathrm{t}$} & \multirow{2}{*}{ Istotność } \\
\cline { 2 - 5 } & $\mathrm{B}$ & $\begin{array}{c}\text { Błąd } \\
\text { standardowy }\end{array}$ & \multicolumn{2}{|c|}{ Beta } & \\
\hline (Stała) &,- 841 &, 463 & & $-1,817$ &, 070 \\
\hline Większość decyzji podejmuje matka &,- 311 &, 126 &,- 085 & $-2,460$ &, 014 \\
\hline Demokratyczny styl kierowania &, 417 &, 136 &, 109 & 3,058 &, 002 \\
\hline $\begin{array}{l}\text { Rodzina jako środowisko pomocne } \\
\text { w kształtowaniu postaw życiowych }\end{array}$ &, 263 &, 081 &, 131 & 3,246 & \multirow{2}{*}{, 001} \\
\hline $\begin{array}{l}\text { Babcia jako osoba pomocna w kształto- } \\
\text { waniu postaw życiowych }\end{array}$ &, 127 &, 051 &, 091 & 2,472 & \multirow{2}{*}{, 014} \\
\hline $\begin{array}{l}\text { Kolega/koleżanka jako osoba pomocna } \\
\text { w kształtowaniu postaw życiowych }\end{array}$ &,- 116 &, 059 &,- 070 & $-1,958$ & \multirow{2}{*}{, 051} \\
\hline $\begin{array}{l}\text { Satysfakcja ze sposobu funkcjonowania } \\
\text { rodziny }\end{array}$ &, 166 &, 077 &, 099 & 2,146 & \multirow{2}{*}{, 032} \\
\hline $\begin{array}{l}\text { Sposób wychowania dzieci jako wzór do } \\
\text { naśladowania }\end{array}$ &, 352 &, 073 &, 231 & 4,822 & \multirow{2}{*}{, 000} \\
\hline Matka jako autorytet &, 207 &, 072 &, 120 & 2,884 &, 004 \\
\hline $\begin{array}{l}\text { Układ dwóch podsystemów (rodziców } \\
\text { i dzieci) }\end{array}$ &,- 659 &, 193 &,- 125 & $-3,416$ & \multirow{2}{*}{, 001} \\
\hline
\end{tabular}




\begin{tabular}{|l|c|c|c|c|c|}
\hline Koalicje równoległe &,- 503 &, 195 &,- 098 & $-2,574$ &, 010 \\
\hline $\begin{array}{l}\text { Koalicja dzieci z matką w opozycji do } \\
\text { ojca }\end{array}$ &,- 409 &, 155 &,- 111 & $-2,633$ &, 009 \\
\hline $\begin{array}{l}\text { Koalicja dzieci z ojcem w opozycji do } \\
\text { matki }\end{array}$ & $-1,484$ &, 565 &,- 090 & $-2,626$ &, 009 \\
\hline $\begin{array}{l}\text { Układ rozproszony (wszyscy w dystansie } \\
\text { do siebie) }\end{array}$ &,- 592 &, 282 &,- 087 & $-2,100$ &, 036 \\
\hline $\begin{array}{l}\text { Prezentuje pozytywne emocje obojgu } \\
\text { rodzicom, ale nie rodzeństwu }\end{array}$ &, 639 &, 217 &, 105 & 2,951 &, 003 \\
\hline $\begin{array}{l}\text { Prezentuje negatywne emocje przede } \\
\text { wszystkim rodzeństwu }\end{array}$ &,- 358 &, 173 &,- 073 & $-2,069$ &, 039 \\
\hline $\begin{array}{l}\text { Prezentuje negatywne emocje obojgu ro- } \\
\text { dzicom, ale nie rodzeństwu }\end{array}$ &,- 582 &, 379 &,- 052 & $-1,537$ &, 125 \\
\hline
\end{tabular}

Zbudowany na podstawie wyników badań grupy młodzieży akademickiej model wyjaśnia 39\% wariancji poziomu poczucia funkcjonalności ich rodzin pochodzenia. Model tworzy szesnaście predyktorów (czynników), z których siedem tłumaczy prawdopodobieństwo wystąpienia wysokiego poziomu poczucia funkcjonalności w grupie badanych studentów, a pozostałych dziewięć tłumaczy prawdopodobieństwo jego niewystąpienia. Schemat 1 ukazuje dwie grupy predyktorów, nazwanych pozytywnymi (zależność wprost proporcjonalna) i negatywnymi (zależność odwrotnie proporcjonalna), spośród różnych elementów deklaratywnego obrazu systemu rodzinnego oraz źródeł kształtowania postaw życiowych badanych studentów.

O zmienności poczucia funkcjonalności rodzinnej badanej grupy studentów decyduje wiele czynników związanych ze specyfiką funkcjonowania systemu rodzinnego, w podobnie liczebnym rozkładzie tych, które sprzyjają jego osiąganiu, jak i tych, które zmniejszają prawdopodobieństwo jego wystąpienia. W świetle wyników prezentowanych badań szanse wystąpienia poczucia funkcjonalności rodzinnej zwiększa deklaracja badanych, iż sposób wychowania dzieci realizowany przez ich rodziców jest dla nich wzorem do naśladowania. Pomocna jest też wysoka ranga środowiska rodzinnego oraz babci w procesie kształtowania postaw życiowych osób badanych. Prawdopodobieństwo wystąpienia poczucia funkcjonalności zwiększa również demokratyczny styl funkcjonowania występujący w rodzinach pochodzenia respondentów, deklaracja prezentowania pozytywnych emocji obojgu rodzicom z pominięciem rodzeństwa, uznanie matki jako autorytetu dla badanych studentów oraz wysoki poziom ich satysfakcji ze sposobu funkcjonowania rodziny pochodzenia. Na drugim biegunie możemy zaobserwować predyktory, których pojawienie się zwiększa prawdopodobieństwo niewystąpienia poczucia funkcjonalności rodzinnej. 
Schemat 1 . Predyktory poczucia funkcjonalności rodziny pochodzenia badanej młodzieży akademickiej

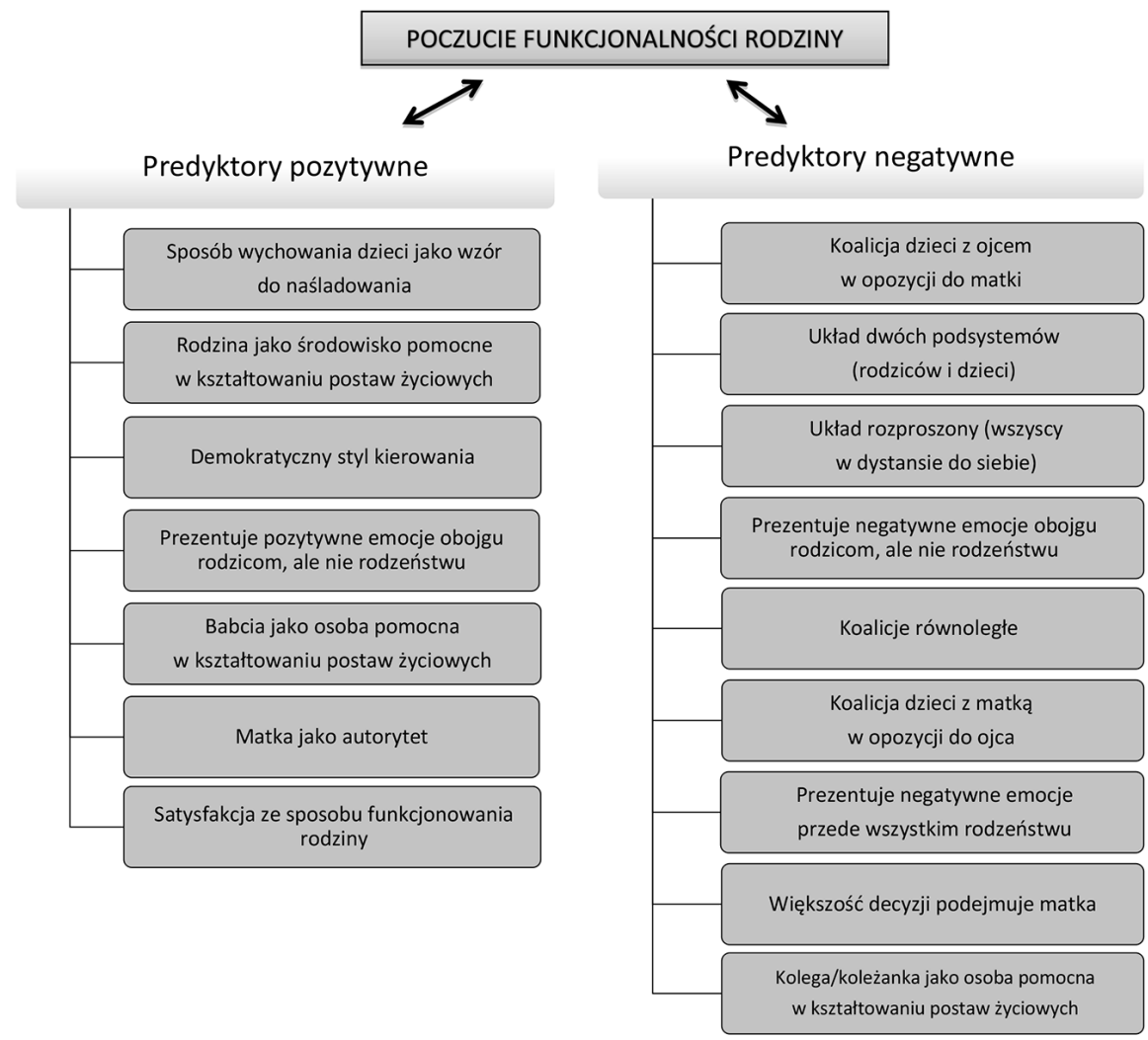

Do tej grupy czynników należą różnego rodzaju układy rodzinne, od struktury złożonej z dwóch podsystemów (rodziców i dzieci), poprzez układy koalicyjne (zarówno równoległe, jak i jednego rodzica z dziećmi w opozycji do drugiego z rodziców), aż po układ rozproszony (gdzie każdy z członków rodziny jest w dystansie do pozostałych). Zmniejszeniu prawdopodobieństwa wystąpienia poczucia funkcjonalności sprzyja też sposób prezentowania emocji, tych negatywnych rodzicom z pominięciem rodzeństwa, a pozytywnych okazywanych przede wszystkim rodzeństwu. Czynnikiem odwrotnie proporcjonalnym był również deklarowany dominujący, większościowy poziom decyzyjności realizowany przez matkę w przestrzeni rodziny pochodzenia badanych studentów. W tej samej grupie negatywnych czynników była deklaracja, że to grupa rówieśnicza (kolega/koleżanka) jest ważną przestrze- 
nią kształtowania postaw życiowych badanych studentów. Generalnie można zauważyć prawidłowość polegającą na tym, że poczucie funkcjonalności rodzinnej zwiększa się wraz z silniejszą demokratyzacją życia rodzinnego, w opozycji do skoncentrowania władzy w ręku jednego rodzica. Pokazuje to potrzebę, którą zgłaszają w świetle własnych deklaracji badani, uwzględniania ich osoby w procesach decyzyjnych dotyczących funkcjonowania systemu rodzinnego. Korzystne wydaje się również uwolnienie ekspresji emocji pozytywnych w kierunku rodziców, przy jednoczesnej niekorzystnej roli okazywania emocji negatywnych kierowanych zarówno w stronę rodziców, jak i rodzeństwa. W jakiejś mierze ukazuje to nadal obecną blokadę na ekspresję trudnych emocji, których nieumiejętność przyjęcia może skutkować elementami destabilizacji relacji wewnątrzrodzinnych. Sprzyjająca jest też wysoka ranga rodziny i pojedynczych jej członków w procesie budowania postaw życiowych oraz akceptacja przez badanych autorytetu rodziców. Niekorzystne natomiast wydaje się przerzucenie wysokiej rangi opiniotwórczej na rzecz grupy rówieśniczej, które może być konsekwencją odczuwanego przez badanych braku zrozumienia przez członków rodziny i poszukiwania przestrzeni akceptacji poza systemem rodzinnym. Elementem utrudniającym osiąganie wysokiego poczucia funkcjonalności rodzinnej są wszelkiego rodzaju układy rodzinne, oparte zarówno na bazie podsystemów, poprzez ich silnie rozproszony charakter, aż po różnego rodzaju koalicje, których natura zwiększa tendencje rywalizacyjne w systemie. Może to ukazywać pewnego rodzaju nieadekwatność tradycyjnego sposobu obrazowania konstrukcji rodzinnej, opartej na układach, które w pokoleniu badanych studentów wydaje się nie odzwierciedlać zmian społecznych, tendencji płynnych konstrukcji i układów, podlegających ciągłym dekonstrukcjom i rekonstrukcjom (Melosik, 1998, ss. 45 - 51). Korzystne natomiast są wzory ról rodzicielskich realizowanych przez rodziców oraz silna aprobacja sposobu funkcjonowania rodziny, co - jak można przyjąć - staje się elementem preferowanych konstrukcji w obrazie antycypowanej przyszłej wizji budowania własnych już systemów przez badanych studentów.

\section{Podsumowanie}

Analizy prezentowanego modelu dotyczącego poczucia funkcjonalności rodzinnej ukazują obraz młodzieży akademickiej, która w swoich orientacjach życiowych bardzo ceni rodzinę, jako podstawowy punkt odniesienia w konstrukcie ich własnej tożsamości. Widoczne jest duże zorientowanie 
na wspólnotowy charakter jej funkcjonowania, jakość relacji poszczególnych członków systemu oraz możliwość własnego partycypowania w zasadach i regułach wypracowywanych w rodzinie. Kształtująca się w nich tożsamość rodzinna jest pewnego rodzaju negocjowanym tworem uznanych przez nich tradycji rodzinnych, z jednoczesnymi zarysowanymi tendencjami dekonstrukcji dotychczasowych modelowych sposobów ujmowania struktury rodzinnej, na rzecz poszukiwania innego spojrzenia, które jest rodzajem adaptacji systemu do dynamicznie zmieniających się warunków społeczno-kulturowych. W świetle wyników analiz modelu, zarysowała się też potrzeba ekspozycji i eksploracji na poziomie emocjonalnym w przestrzeni środowiska rodzinnego, co może stanowić wyzwanie dla potrzeb budowania metodycznych strategii wsparcia systemów rodzinnych.

Prezentowane wyniki badań można potraktować jako pretekst do szerszej dyskusji na temat sposobów konstruowania koncepcji badawczych dotyczących systemu rodzinnego. Myślę, że czym bardziej zróżnicowane spektrum narzędzi badawczych i uruchamianie różnego poziomu analiz, tym większe prawdopodobieństwo zobiektywizowania obrazu. Może to w konsekwencji być pomocne w tworzeniu strategii zarówno prewencyjnych, jak i interwencyjnych, w przestrzeni, wydaje się, najistotniejszej społecznie, jaką jest rodzina. Badania tego typu wkomponowują się w próbę dookreślenia procesów kształtowania się tożsamości młodego pokolenia. W doświadczeniu ludzkiej tożsamości zawarte są dwa istotne, przenikające się elementy: poczucie przynależności i poczucie odrębności. System rodzinny te dwa elementy procesu zarówno wytwarza, rozdziela, jak i reguluje w toku procesu socjalizacji i wychowania. Umiejętność zachowania równowagi pomiędzy procesami rozwojowymi (morfogenetycznymi) i tendencjami do zachowania stałości (morfostatycznymi) jest niezbędnym elementem utrzymania tożsamości systemu rodzinnego (Janicka i Liberska, 2014, ss. 24-25). Próba zbadania „śladu”, który pozostawił sposób funkcjonowania rodziny pochodzenia w układzie tożsamościowym młodego pokolenia, może być pomocna w próbie antycypacji zmian społecznych, przede wszystkim w kontekście zmian kształtu systemów rodzinnych, jako grup budujących podstawę ładu społecznego. 


\section{Bibliografia}

Antonovsky, A. 1995. Rozwiktanie tajemnicy zdrowia. Jak radzić sobie ze stresem i nie zachorować. Warszawa: Fundacja IPN.

Bajkowski, T. 2018. U źródet tożsamości rodzinnej. System rodzinny w percepcji młodzieży akademickiej. Warszawa: Wydawnictwo Naukowe Scholar.

Barbaro, B. red. 1999. Wprowadzenie do systemowego rozumienia rodziny. Kraków: UJ.

Barbaro, M. 1999. Struktura rodziny. W: Barbaro, B. red. Wprowadzenie do systemowego rozumienia rodziny. Kraków: UJ.

Beavers, R. and Hampson, R.B. 2000. The Beavers Systems Model of Family Functioning. Journal of Family Therapy. 22, pp. 128-143.

Bowen, M. 1978. Family therapy in clinical practice. New York: Jason Aronson Inc.

Bronfenbrenner, U. 2005. Making human beings human: Bioecological perspectives on human development. California: Thousand Oaks.

Gaś, Z.B. 1994. Uzależnienia. Skuteczność programów profilaktycznych. Warszawa: WSiP.

Gaś, Z.B. 2004. Inwentarz Profil Rodziny jako narzędzie kompleksowej diagnozy systemu rodzinnego. W: Gaś, Z.B. red. Badanie zapotrzebowania na profilaktykę w szkole. Poradnik dla szkolnych liderów profilaktyki. Lublin: Wyd. Masz Szansę.

Grzesiuk, L. 1987. Strukturalna terapia rodziny w ujęciu Minuchina. Nowiny Psychologiczne. 1, ss. 33-48.

Józefik, B. 2003. Rozwój myślenia systemowego a terapia rodzin. W: Górniak, L. i Józefik, B. red. Ewolucja myślenia systemowego w terapii rodzin. Od metafory cybernetycznej do dialogu i narracji. Kraków: UJ.

Kaleta, K. 2011. Rodzinne uwarunkowania społecznego funkcjonowania jednostek w świetle teorii Minuchina i Bowena. Rocznik Psychologiczny. 14 (2), ss. 141-158.

Melosik, Z. 1998. Wychowanie obywatelskie: nowoczesność, ponowoczesność. W: Melosik, Z. i Przyszczypkowski, K. red. Wychowanie obywatelskie. Studium teoretyczne, porównawcze i empiryczne. Toruń-Poznań: Edytor.

Miller, I. W., Ryan, C.E., Keitner, G.I., Bishop, D.S. and Epstein, N.B. 2000. The McMaster Approach to families: theory, assessment, treatment and research. Journal of Family Therapy. 22, pp. 168-189. 
Minuchin, S. 1974. Families and family therapy. Cambridge: Harvard University Press.

Olson, D.H. 2011. FACES IV and the Circumplex Model: validation study. Journal of Marital and Family Therapy. 1 (37), pp. 64-80.

Olson, D.H., Sprenkle, D.H. and Russell, C. 1979. Circumplex model of marital and family systems: cohesion and adaptability dimensions, family types, and clinical applications. Family Process. 18, pp. 3-28.

Paufal-Struzik, I. i Szewczyk, A. 2016. Poczucie funkcjonalności systemu rodzinnego a postawa twórcza młodzieży. Społeczeństwo i Rodzina. 1 (46), ss. 69-85.

Przetacznik-Gierowska, M. 2002. Psychologia wychowania. W: PrzetacznikGierowska, M. i Włodarski, Z. red. Psychologia wychowawcza. Tom 2. Warszawa: PWN.

Rostowski, J. 2006. Jakość życia rodzinnego w kontekście teorii systemowej. Pedagogika Rodziny. 1, ss. 127-143.

Skinner, H., Steinhauer, P. and Sitarenios, G. 2000. Family Assessment Measure (FAM) and Process Model of Family Functioning. Journal of Family Therapy. 22, pp. 190-210.

Walsh, F. 2012. Family resilience. Strengths forged through adversity. W: Walsh, F. ed. Normal family processes. Growing diversity and complexity. New York: Guilford Publications.

Werner, I. 2013. Poczucie rodzinnej koherencji - pojęcie oraz implikacje psychopedagogiczne. W: Piorunek, M., Kozielska, J. i Skowrońska-Pućka, A. red. Rodzina - Młodzież - Dziecko. Szkice z teorii i praktyki pomocy psychopedagogicznej i socjalnej. Poznań: UAM.

\section{The feeling of family functionality in the perception of university students from the North-Eastern borderland of Poland}

Abstract: The family is the environment that leaves its mark and imprint the
most in the structure of the human identity. This is because of both the broadly
reaching and permanent character of impacts. Every family creates and regulates
its peculiar familial identity. The text presents the results of research conducted
in the group of academic youth regarding the sense of family functionality and an
attempt to capture the determinants of them. Analyzes of the presented models
show the image of academic youth who, in their life orientations, highly values the
family as the basic reference point in the construction of their own identity. There
is a visible focus on the community nature of its functioning, the quality of the 
relations of individual members of the system and the possibility of participating in the rules and rules developed in the family. The family identity that develops with said rules is a kind of negotiated creation of the family traditions recognized by them, with simultaneous outlined tendencies of deconstruction of the existing model ways of capturing the family structure, in favor of seeking a different view, which is a kind of adaptation of the system to dynamically changing socio-cultural conditions.

Keywords: family system, family identity, identification, youth, sense of family functionality, intercultural education

Translated by Tomasz Bajkowski 